\title{
The Effect of Interactional Adjustments on the Overall Comprehension of Spoken Texts: A Case Study
}

\author{
Marcos Peñate \\ Geraldine Boylan \\ University of Las Palmas de Gran Canaria, Spain
}

One of the basic conditions required for pupils to learn a foreign language is that their teachers must speak to them in the target language-and always at a level which is understandable to them. The effectiveness of interactional adjustments such as repetitions, comprehension checks, and nonlinguistic aspects used by a teacher to help primary and secondary school pupils with their general understanding of spoken texts delivered in English is analysed in this article. Once the effectiveness of such adjustments is confirmed, a comparison is made between the teacher's use of adjustments when teaching a group of 10-year-old primary school pupils and when teaching a group of 17 -year-old secondary school pupils.

外国語指導の重要な要件の一つとして、当該外国語を指導言語とし、しかもそれを学習 者が理解できるレベルで使わなければならないということが挙げられる。そのために教員 は学習者とのやり取りの最中、理解の確認、繰り返し、あるいは非言語行動により絶えず 調整を行わなければならない。このような調整がどのくらい効果があるのかを、小学校、 中学校の授業を観察し分析した。さらに10歳の小学生対象の授業、17歳の中学生対象の授 業でどのように違うかをあわせて考察した。

JALT Journal, Vol. 27, No. 2, November, 2005 
7 he teaching of foreign languages to primary school children in Europe has been introduced gradually over the last decade, as is 1 the case now in Japan. The decision to teach foreign languages in Japanese primary schools is not trouble free, especially for teachers of English who are now faced with the problem of having to start teaching completely new age groups as well as adapting their teaching skills and classroom activities to the cognitive constraints of this level. In secondary schools we still frequently find that foreign language teaching is based on the formal aspects of language, for example, grammar. Such marked formal constraints are unsuitable for teaching foreign languages in primary schools, as for many pupils they do not encourage the development of positive motivation towards the language being learned. Consequently, primary school teachers have to adopt an approach which is in accordance with the age and intellectual capacity of the average primary school child.

After many years of debate, particularly between Krashen (1998) and Swain (1993), there now appears to be a consensus of opinion regarding the minimum number of indispensable elements which should be present in the classroom in order to enhance the learning of a foreign language. Firstly, the teacher must speak to his pupils in the target language in such a way that they can understand him. Secondly, the learners must be under constant pressure to use the target language to the full extent of their capacity. Finally, target language learning must always include a metalinguistic function.

Of the above-mentioned conditions, the first one places special emphasis on the role of the teacher, particularly when he or she attempts to achieve one of the main objectives in the foreign language syllabus for primary and secondary school pupils, which is to help the pupils grasp the overall meaning of an oral text.

Perhaps one of the most important challenges has been defining what is meant by the concept of "overall comprehension" of an orallydelivered text, since it has been found that many school teachers have a rather limited view of the concept. Frequently, the testing of overall comprehension is limited to answering-in a very general way-the question, "What is the text you have just heard, about?" This attempt to develop pupils' general understanding is a direct consequence of the traditional type of listening activities that have been used in schools. In the vast majority of cases, tape cassettes have been the major source of material for listening activities, thus have often resulted in students at both primary and secondary school levels having difficulties in follow- 
ing the basic line of the text they are listening to. On the other hand, pupils appear to have far greater success in understanding an oral text if it is delivered directly by the teacher.

Up until the 1980s, the field of language teaching had taken the acquisition of listening skills for granted (Morley, 1991), and they were most certainly not given the attention they deserved as far as research was concerned. This was a direct consequence of the teaching methods generally used, which placed considerable emphasis on the teaching of the formal aspects of language.

It was from the 1980s onwards that the development of listening skills was finally given the attention it deserved. This was later reinforced when the importance of listening skills in the acquisition of a foreign language was recognised. Within the framework for exploring second language acquisition proposed by Ellis (1994), out of the four different areas which have undergone research (learner language, external factors, internal factors, and individual differences), several studies relating to listening skills can be found in at least two of the areas-external factors and individual differences. In these studies, various individual learner differences, their causes, and some of the many influential factors which are external to the learner are discussed.

Learners acquire a foreign language in many different ways, which justifies the study of individual learner differences. Many specialists have concentrated on looking into the effects that factors such as memory, age, motivation, background knowledge, and aptitude can have on the acquisition of a foreign language. Much has focussed on individual learning strategies of oral comprehension. For example, Call (1985) studied the relationship between listening skill and short-term memory, in particular for musical notes, digits, words, and sentences. The data obtained indicated that only short-term memory for sentences was an important component of listening comprehension, whereas words, digits, and tonal memory had a weaker relationship with the listening scores. Likewise, Seright (1985) examined the relationship between age and second language achievement. She compared older (aged 25 to 41) and younger (aged 17 to 24) learners. Her study suggests that in adult learners the rate of achievement in aural comprehension decreases with age. Van Patten (1990) explored the question of whether or not learners could consciously attend to both form and meaning when processing input and discovered that early-stage learners have great difficulty in attending to both. That is, conscious attention to form in the input competes with conscious attention to meaning and only when the input is easily 
understood can learners attend to form. In the same way, Taguchi's study (2001) offers insight into some of the second language learners' strategic mental processes during a listening comprehension test and points out that more proficient listeners utilized a greater range of strategies.

Studies looking at external factors relating to the environment in which learning takes place have also paid special attention to listening skills. Here, input and interaction play a key role. Two lines of research have addressed how a spoken text delivered by the teacher can be made more understandable to the listener.

The first line of research has studied simplified input and has tried to determine which grammatical, lexical, and phonological modifications are necessary in order to produce a spoken text which is more comprehensible to the learner. Grammatical modifications include:

1) Reduction in the length of utterances, where a tendency to use shorter utterances with pupils of a lower linguistic level is seen (Kleifgen, 1985).

2) Simplification of syntax with pupils of a lower level, for example, avoiding the use of subordinate clauses (Henzl, 1973).

3) The use of various types of questions is one of the most frequently recurring characteristics in the language used by teachers (Wagner-Gough \& Hatch, 1975). It has been shown that the easiest type of questions (What and Where) appear before more difficult types (How and When), which in turn appear before questions that begin with Why.

4) A distinct tendency to opt for simple verb tenses (present, future, etc.) instead of more complex forms (the passive voice, conditionals, etc.) is seen as a further grammatical modification used by teachers (Henzl, 1979).

5) A high number of grammatically correct phrases spoken by teachers when addressing their pupils is usually considered one of the most significant aspects of their input (Hakansson, 1986).

Lexical modifications are characterised by simple and frequently used vocabulary (Saville-Troike, 1985). Finally, within this line of research, phonological modifications, illustrated by a reduced speed of 
delivery (Enright, 1986) and slight exaggeration in accent and intonation particularly when addressing children, are also found (Scarcella \& Higa, 1981, 1982).

The second more recent line of research suggests that teachers can make their input more comprehensible by using a series of interactional adjustments. Moreover, it should be borne in mind that excessively simplified linguistic input may not be the most appropriate when dealing with mixed-ability classes since it could deprive those pupils who have a more advanced level of language of adequate input and thus possibly cause them to reject the language they are learning. To avoid this, the standard of linguistic input should be maintained and as many interactional adjustments as necessary should be used to help the lesser able pupils with their foreign language comprehension. In this sense, as Larsen-Freeman and Long (1991) point out, the use of interactional adjustments is more effective and thus more important than simplified input.

These interactional adjustments can be put into three groups: repetitions, comprehension checks, and nonlinguistic aspects. The first of these includes partial or total repetition of what has been said in the previous speech units (Scarcella \& Higa, 1981). Although repetitions are characteristic of the way teachers communicate with child learners, they are also used, although more elaborately, when addressing adult learners. In a study carried out by Cervantes and Gainer (1992), it was shown that a group of Japanese university students who were learning English as a foreign language achieved higher levels of comprehension when repetitions were used.

According to Wong-Fillmore (1982), it is clear that when comprehension checks are used as an interactional adjustment, they are aimed at encouraging pupil participation. The teacher's intention is to attract the attention of the learners and invite them to anticipate what he or she is going to say next. As Hakansson (1986) suggests, this could explain why teachers sometimes opt to leave sentences or phrases unfinished as an alternative to asking questions. If the pupils have been following what the teacher has been saying, they have the opportunity to complete the unfinished phrases or sentences as can be seen in the example provided by Hakansson (p. 92): "How old is Mats? Mats is ..."

Moreover, rhetorical questions, which are logically answered by teachers themselves, are used as resources in narratives, thereby helping the pupils to focus their attention on what is going to be said next (Scarcella \& Higa, 1982). Questions formed by using "OK?" or "All right?" 
are designed to check or confirm that the pupils understand what is being narrated (Pica and Long, 1986). Their understanding is frequently confirmed by a mere nod of the head.

The last of the interactional adjustments deals with some nonlinguistic aspects of foreign language teaching. Studies which have attempted to determine and analyse the role of the foreign language teacher have paid little attention to the use teachers make of nonlinguistic aspects. One exception has been an analysis of the use teachers make of visual resources (Tardif, 1994). The study of body language (facial features, hand movements, mime, etc.) and its possible impact on pupils in the foreign language classroom has been almost completely ignored.

Both Cook (1993) and Spada (1994) suggest that the presence of certain features in the teachers' speech does not automatically mean that they make their pupils' comprehension of a spoken text any easier. These authors suggest the need for further studies demonstrating that specific interactional adjustments used by teachers might help students improve their understanding of what is being said. Moreover, these studies could provide guidance to classroom teachers (Dunkel, 1991). Several years earlier, Ellis (1985) also pointed out the need to ascertain whether the linguistic modifications and the interactional adjustments used by the teacher indeed change according to the level of learner competence.

Most studies to date have taken place in an ESL context. As what is applicable in an ESL context is not necessarily applicable in an EFL classroom, and to help fill in some of the gaps in the research, the present EFL study was carried out in a school in the city of Las Palmas in the Canary Islands.

\section{Method}

For the experiment, two groups of 30 primary school pupils and two groups of 35 secondary school pupils were formed. For each level, one of the two groups was used as the experimental group whilst the other was used as the control group (see Table 1).

The main aim of this study was to consider the use the same teacher made of interactional adjustments (repetitions, comprehension checks, and gestures) whilst telling one story in English to 10-year-old primary school pupils and a different story to 17 -year-old secondary school pupils. Two interesting questions arose from this aim: To what extent is the use of repetition, comprehension checks, and gestures important in aiding the comprehension of both age groups and what are the differences 
Table 1. Experiment design

\begin{tabular}{lllc}
\hline Level & \multicolumn{2}{c}{ Groups } & Text \\
\hline Primary & Experimental (30) & Control (30) & A \\
Secondary & Experimental (35) & Control (35) & B \\
\hline
\end{tabular}

in how they are used? The teacher who participated in the study, a native speaker of Spanish, was chosen because of her good level of English and because she had had teaching experience with both primary and secondary school pupils.

\section{Materials}

Two texts (A and B) which were considered adequate in terms of linguistic content and subject matter were chosen and adapted according to the pupils' general language level. Adjustment to suitable levels was made bearing in mind that the listening activity was intended to help develop the skill of overall comprehension of a spoken text. That is, the pupils were not expected to understand every word spoken. The text chosen for the primary school pupils was an adaptation of the tale The Long Nose (see Appendix A) which only contained verbs in the simple present and which had five subordinate clauses with because. The secondary school pupils listened to the text When My Friends Come to Visit Us (see Appendix B) in which the simple present was the most frequently-used verb tense although the following tenses also appeared: present continuous, simple past, verb + -ing (like, spend, go on). There were also four subordinate clauses with when, because, as, and so.

No visual representation of the stories was used, thereby avoiding interference with the accurate measuring of the interactional adjustments employed in each case. Thus, the problem pointed out by Rubin (1994, p. 205) when she says that "the images may correlate fairly closely with the conversation, at times even to the point of negating the need to listen at all!" was avoided.

\section{Procedures}

Both texts were given to the teacher several days before they were to be read to the pupils. In the days running up to the experiment, she was asked to read the text several times so that she almost memorized it. 
The teacher was also asked to make copies of both texts using a font size large enough to enable her to read them from her desk top without having to hold them. As well as this, she was asked to mark the places in the text where she would pause in the narration. Because of these requests, there was a greater assurance that the teacher would only look at the text during the predetermined pauses and so when she was talking to the pupils, she would look at them and not at the text.

On the day of the experiment, whilst the teacher told the story to the control group, she took advantage of the pauses to look at the text. With the experimental group a similar process was followed, but this time, the teacher could make use of as many repetitions, comprehension checks, and gestures as she considered necessary in order to help the pupils understand the stories that were being told. A tape recorder was used and recordings of the stories were made so that all linguistic input could be transcribed. All gestures used by the teacher were recorded on a video camera.

After listening to the story, all the students had to complete a test (marked on a scale of 0 to 10), which measured their level of comprehension. With the primary school pupils, a test set in their mother tongue (Spanish) was used whilst a test set in English was used for the secondary school pupils, although their level of accuracy in written English was not able to be taken into account.

\section{Results}

The scores obtained by the experimental group of primary school pupils were distributed towards the higher end of the scale, whilst those of the control group were situated at the lower end (see Figure 1). The mean of the experimental group doubled that of the control group. The control group scored a mean of 2.90 with a standard deviation of 2.17, whilst the experimental group obtained a mean of 6.20 , with a standard deviation of 2.37 .

A similar outcome was found among the secondary school pupils. Figure 2 shows the tendency towards an accumulation of scores at the lower end of the scale for the control group whilst the inverse occurs in the experimental group. The secondary school pupils, the mean of the control group was 3.46, with a standard deviation of 2.63, whilst the mean of the experimental group rose to 7.29, the standard deviation being 2.47. Once again, the experimental group doubled the mean obtained by the control group. Moreover, the standard deviations are very similar. 


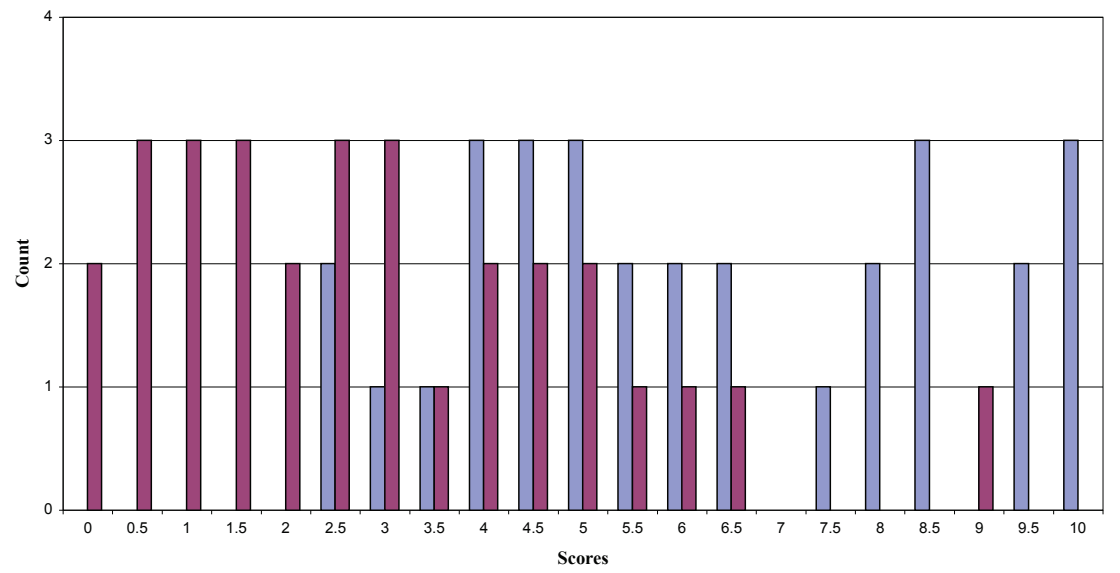

$\square$ experimental group $\square$ control group

Figure 1 . Scores obtained by the primary school pupils

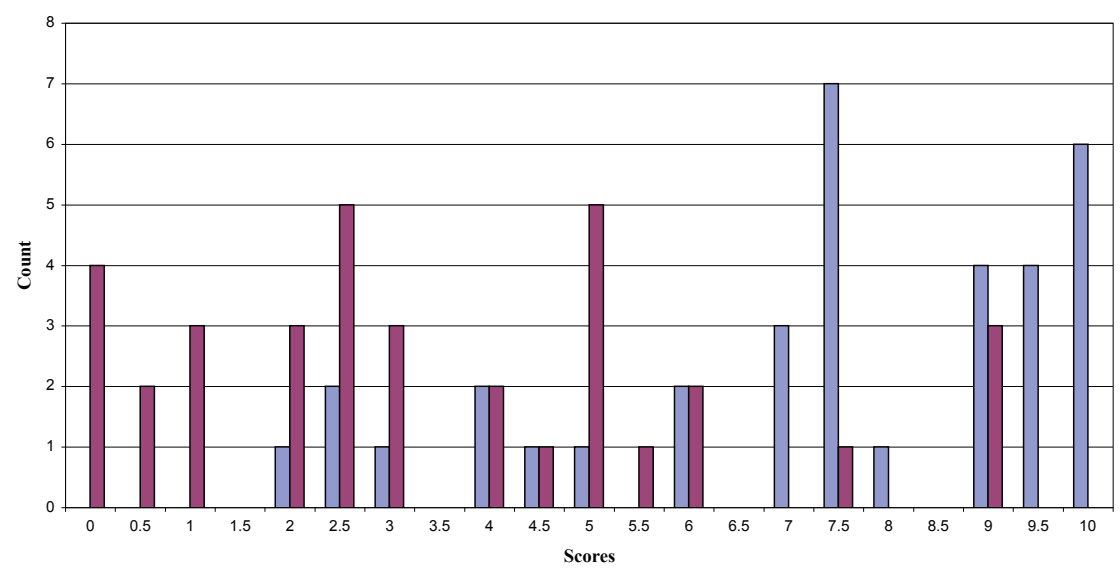

$\square$ experimental group $\square$ control group

Figure 2. Scores obtained by the secondary school pupils

Statistical analysis carried out on these results allowed us to corroborate whether or not there were significant differences between the results obtained in each age group according to the way the story was narrated. But since two independent groups were being studied in each 
case, whether the groups compared had equal variances or not had to be established. In order to do this, Levene's test for equality of variances was applied. When comparing the two primary school groups, the value obtained for Levene's test was 0.901 , with a probability of 0.35 , and with the secondary school groups, the value was of 0.32 , with a probability of 0.58 . In both cases, the probability is higher than 0.05 , which implies that equal variances are assumed.

With the results obtained from the tests, and by means of an independent sample t test (SPSS for Windows), it was possible to establish that there were significant differences between the scores obtained by the two groups of primary school pupils at the 0.05 level. The same occurred with the secondary-level scores (see Tables 2 and 3).

Table 2. Test scores, primary school pupils

\begin{tabular}{llcc}
\hline Variable & Cases & Mean score & $\begin{array}{c}\text { Standard } \\
\text { deviation }\end{array}$ \\
\hline $\begin{array}{l}\text { Experimental } \\
\text { group }\end{array}$ & 30 & 6.2000 & 2.3693 \\
$\begin{array}{c}\text { Control group } \\
\text { T value }\end{array}$ & 30 & 2.9000 & 2.1672 \\
5.629 & Degrees of freedom & Probability \\
\hline \multicolumn{2}{c}{58} & 0.000 \\
\hline
\end{tabular}

Table 3. Test scores, secondary school pupils

\begin{tabular}{llcc}
\hline Variable & Cases & Mean score & $\begin{array}{c}\text { Standard } \\
\text { deviation }\end{array}$ \\
\hline $\begin{array}{l}\text { Experimental } \\
\text { group }\end{array}$ & 35 & 7.2857 & 2.4653 \\
Control group & 35 & 3.4571 & 2.6245 \\
T value & Degrees of freedom & Probability \\
6.290 & \multicolumn{2}{c}{68} & 0.000 \\
\hline
\end{tabular}


As can be seen in Tables 2 and 3, the probability is lower than 0.05, which leads to the conclusion that there were significant differences between the scores obtained by the experimental group and the control group of each level.

In several studies, where the results obtained are similar to those presented above, the conclusion reached is that with the use of interactional adjustments, the level of pupil comprehension is statistically higher. However, it is essential to verify that the interactional adjustments made with the experimental groups did not simplify the linguistic input.

As explained above, the primary-level text, The Long Nose, only contained verbs in the simple present and five subordinate clauses with because. With the experimental group, as well as the simple present, the simple past was used on eight occasions, going to was used eleven times, the present continuous was used twice and the present perfect, once. Six subordinate clauses containing because, so, or when were also used. The average length of utterance in both the control and experimental groups was almost identical: 3.68 and 3.72 words respectively. Also, the percentages of different words used in the two group situations are similar (control group, 19.1\%; experimental group, 20.6\%).

In the secondary classroom, differences in use of verb tenses between the control and experimental groups were not found. However, although the same types of subordinate clauses were used with both groups, only four were used with the control group while 21 were used with the experimental group. Both the control and experimental groups had almost identical mean length of utterances, 6.17 and 6.09 respectively. With regard to the percentage of different words used in both experimental situations, the control group had a higher percentage than the experimental group ( $53 \%$ and $41.5 \%$ respectively).

From this information, it can be established that the linguistic difficulty of the texts used with the experimental groups was not inferior to the linguistic difficulty of the texts used with the control groups. Consequently, the interactional adjustments used must be analysed in order to explain why the students in the experimental groups achieved better levels of comprehension.

\section{Interactional Adjustments Used by the Teacher}

Once it was proven that the interactional adjustments used by the teacher aided the comprehension of both the primary and secondary pupils, the differences in how the adjustments were used was studied. 
Using the data gathered from the transcripts, videotapes and field notes, the use made by the teacher of interactional adjustments (repetitions, comprehension checks, and supportive gestures) was analysed.

\section{Repetitions}

Repetition is one of the most frequent features in conversations held between parents and young children when they are learning their mother tongue. Likewise, repetition is an interactional adjustment used regularly by teachers in order to help their pupils achieve a higher level of comprehension. These repetitions are different from those used in the drills found in the audiolinguistic teaching method. Rather, they fulfil the function of reinforcing the meaning of what has been said previously. They can be either total or partial repetitions of the same words already spoken or they can be a repetition of the meaning using synonyms, for example, "Teacher: You can answer either affirmatively or negatively. You can answer either by yes or by no." (Hamayan \& Tucker, 1980, p. 463). This last type of repetition is usually referred to as paraphrasing.

On counting the number of repetitions used by the teacher in the study, it became obvious in a later interview that she had not been totally aware of the high number of repetitions she had used when telling the story to the primary school pupils. These total or partial repetitions (103 examples) were repetitions of something she had already said in one of the three units of speech that preceded the repetition. There were also 23 instances of repetitions of something which had been said by the pupils, which gives a total of 126 . In other words, $30 \%$ of the speech units (SU) uttered contained repetitions. Two examples of paraphrasing ${ }^{1}$ were also found. Both examples were used to define a word that the teacher believed the pupils to be unfamiliar with. Such was the case with the word sell, which was explained with the paraphrase "When you give something and they give you money" (SU 228).

In the case of the primary school pupils, a distinction was made between the repetitions made by the teacher of something uttered by the teacher herself and repetitions made by the teacher of something the pupils had said. However, with the secondary school pupils, there were no examples of this second type of repetition because the pupils said nothing whilst the story was being narrated. Here, there were 21 instances in which the teacher partially or totally repeated something which she herself had uttered. Moreover, it was also noted that the teacher repeated the same structure in consecutive speech units, as in: 
SU 80: because my wife can speak some foreign languages

SU 81: She can speak German.

SU 82: She can speak French.

SU 83: She can speak English.

There are 17 cases where the teacher made use of this last type of repetition. If the two types of repetition are added together, they total 38 , which is $21.8 \%$ of the total number of speech units uttered. She resorted to paraphrasing on two occasions in order to explain the meanings of two words the pupils were unfamiliar with. An example is found in SU 88-90: Teacher: Do you know what stamps are? [The pupils do not respond.] These little things you put on the envelopes when you want to send a letter to England or France.

\section{Comprehension Checks}

As mentioned in the introduction, the two adjustments used to check pupil comprehension were questions and unfinished sentences. Using questions as a means of keeping a conversation going or simply as a way of holding the attention of the pupils is probably one of the resources most frequently employed by teachers. Results show that the teacher made good use of this strategy whilst in contact with the primary school pupils. Sixty-two cases were detected and are divided as follows:

1) Questions to check whether or not the pupils were following the story being told: 26 cases. Some examples of these speech units are OK? (SU 48) and Yes? (SU 19).

2) Display questions or questions whose answers the teacher already knew because they referred to something that had already been mentioned: 19 cases. Some examples are What is the name of the boy in this story? (SU 40), and How old is Pedro? (SU 88).

3) Referential questions or questions whose precise answers were not known by the teacher although she had a fairly clear idea of how the pupils would answer: 14 cases. Examples include Where do you live? (SU 25) and How old are you? (SU 64). These personal questions were asked in the middle of the story in order to ensure that the pupils were paying attention and that consequently they 
would be prepared to understand the following piece of information. This was also a way of indirectly connecting the pupils' personal experience with the events of the story. So, for example, after asking some pupils where they lived, the teacher went on to tell them where the characters in the story lived.

4) Rhetorical questions or questions that the teacher did not expect the pupils to answer. She provided the answers in the next speech unit: 3 cases. Examples include Do you understand "funny"? Ha, ha! (SU 10 and 11) and What does Tom like? He only likes eating biscuits (SU 198 and 199).

Contrasting sharply with these results, it was found that with the secondary pupils, the teacher's use of this strategy was limited and she only asked seven questions. In all cases, the questions were asked of the group as a whole and the teacher was satisfied if the pupils responded through gestures and facial expressions. The seven questions asked can be divided into two different types:

1) Five were used as a means of testing the pupils' comprehension of what they were listening to, for example, $O K$ ? (SU 38) and All right? (SU 41).

2) Two were open-ended (referential), but their answers were predictable.

In fact, the answers to these questions were so predictable that a gesture from the pupils served satisfactorily (SU 113 and 114):

Teacher: How many people here play chess?

Pupils: [Several pupils raise their hands.]

Teacher: Do you like playing chess?

Pupils: [They nod their heads.]

Using unfinished sentences as a means of checking comprehension was employed only with the primary school pupils. There were numerous examples of unfinished sentences and in all cases, they clearly fulfilled one of two functions: the pupils had to complete the sentence either by repeating what had been said (10 cases) or they had to complete it by predicting a possible conclusion (35 cases). Examples of the first type are His name is... (SU 50) and Tom is ... (SU 138). Examples of 
the second type are They live in... (SU 140) and They have got two hens. They have also got a... (SU 174 and 175).

\section{Nonlinguistic Aspects: Supportive Gestures}

The videos taken during the course of the storytelling were examined in detail and all instances of the teacher making significant gestures were noted. In order to classify the gestures used by the teacher, earlier classification lists (e.g., Kellerman, 1992) and dictionaries of gestures were used as reference points.

The total sum of gestures used by the teacher whilst telling the story to the primary school pupils was 149 , which is the equivalent of $34.7 \%$ in relation to the number of speech utterances used (see Table 4). However, the total number of gestures used with the secondary school pupils was only 31 , the proportion being $17.8 \%$.

Table 4. Gestures used in the primary and secondary classroom

\begin{tabular}{lcc}
\hline Types of gestures & Primary & Secondary \\
\hline Personal identification & 27 & 7 \\
Place & 7 & 3 \\
Time & - & - \\
Affirmation/Negation & 14 & 1 \\
Amount & 8 & 1 \\
Appearance & 22 & 2 \\
Actions & 39 & 10 \\
Orders & 3 & - \\
Feelings & 8 & 5 \\
Greetings & - & - \\
Others & 18 & 2 \\
\hline Total & 146 & 31 \\
Percentage & $34.7 \%$ & $17.8 \%$ \\
\hline
\end{tabular}

\section{Discussion}

The main objective of this study was to see the effectiveness that interactional adjustments (repetitions, comprehension checks, and gestures) had on helping primary and secondary school pupils with their 
general understanding of spoken texts delivered by a teacher in English. From the scores obtained by the pupils on the tests, it was seen that statistically significant differences were present. At both levels, the experimental-group means doubled those of the control groups. Thus, it can be confirmed that the use of repetition, comprehension checks, and gestures is helpful in aiding both primary and secondary pupils with their comprehension of oral texts.

Once the need to continue using interactional adjustments with secondary school pupils was confirmed, whether or not pupil-age-related differences existed in the use of these adjustments became the second point of interest. Here, the differences in use at each level were analysed.

Fewer repetitions were used with secondary school pupils than with the primary pupils (21.8\% and 30\%, respectively). It was also found that those made with the primary school pupils were total or partial repetitions of something that had been said in one of the three previous speech units. However, with the older pupils, the majority of repetitions used were essentially synonyms. Thus, it is clear that with the secondary pupils not only did the number of repetitions used decrease, but also the types of repetitions used were more sophisticated.

The teacher's main aim was to make the pupils understand what she was saying. However, on asking her to explain what her second objective was, it became evident that it varied according to whether she was dealing with primary or secondary school pupils. With the primary school pupils, her objective was simply that they just listen to her as at that age they can be easily distracted. This points to the importance that short-term memory plays in listening comprehension, as pointed out by Call (1985). With the secondary school pupils, the objective was that they recognise and learn new words and linguistic structures such as, "... my wife can speak some foreign languages. She can speak German. She can speak French. She can speak English." The recognition and learning of new words and linguistic structures was not one of the objectives in the case of the primary school pupils because, as Van Patten pointed in his study (1990), early-stage learners have difficulties in attending simultaneously to both meaning and form. The necessity to make the primary school pupils pay attention and help them to become involved in the story also becomes obvious when it is observed that out of the 126 repetitions made by the teacher, 23 of them are words or phrases spoken by the pupils. This phenomenon did not arise with the secondary school pupils. 
The rather high level of participation of the primary school pupils arose because of the use of comprehension checks, which was the second interactional adjustment considered. Here, the differences between the groups are more marked. On telling the story to the primary pupils, the teacher asked 67 questions, whilst with the secondary pupils, only seven examples of questions were found. The questions asked during the storytelling had two basic functions: 1) to check whether or not the pupils were able to follow the story line, and 2) to make sure the pupils were paying attention to the story.

The problems children have with comprehension are frequently rooted in their lack of attention. From our data, it became clear that when the teacher asked the primary school pupils questions, her objective was to maintain their attention. In a later interview, she pointed out that the attention span of a younger child is generally far more limited than that of an older one, thus making the use of questions more of a necessity with younger age groups.

The third aspect of interactional adjustment considered was the use of gestures. In comparison with the primary school pupils, the use of gestures underwent a notable decrease with the secondary school pupils. The percentage of speech units accompanied by gestures decreased from $34.7 \%$ (primary) to $17.8 \%$ (secondary). That is to say, this interactional adjustment, which in the literature had previously not been considered, was clearly one of the factors which helped facilitate better oral comprehension.

\section{Conclusion and Implications for Teaching}

As perceived online by the teacher, the secondary school pupils still needed to rely on the use of repetitions and gestures in order to be able to reach a clearer understanding of the story that was told to them. However, the use of questions as a form of immediate comprehension testing and confirmation of attention hardly occurred; their degree of dependency on these strategies appeared markedly lower than that of the primary school pupils.

From a pedagogical point of view, this study yields several clear implications:

1) From the results obtained and the conclusions reached, it is obvious that the use of suitable interactional adjustments by a teacher whilst helping his or her pupils reach a 
deeper understanding of a spoken text is clearly beneficial to the pupils. Primary school pupils need teachers who are capable of telling them stories using the above-mentioned interactional adjustments. In this way, the pupils should be able to follow the story line of texts at a more sophisticated linguistic level than the one they already possess.

2) Since spoken language is the most common means of communication and the need to understand and to be understood knows no boundaries, the strategies used to reach a greater depth of comprehension should not be limited. Consequently, secondary school pupils should be given the help they need, particularly by the teacher making use of repetitions of linguistic structures and gestures. With these, their comprehension should improve. Moreover, pupils should also be given further opportunities to understand the way in which linguistic structures are used within oral discourse.

3) A considerable difference in level between input and output should be maintained, thus providing the pupils with an opportunity to enrich their language. Adjustments, like those investigated here can contribute considerably to enhancing input.

4) Despite the geographical distance and the considerable sociocultural differences that inevitably exist between primary and secondary schools in Japan and Spain, this study on the effect of interactional adjustments on the overall comprehension of spoken texts in a primary and secondary school setting in the city of Las Palmas could serve as an indicator as to how successful this strategy could be if used in similar school settings in Japan.

5) If these types of activities were to be carried out at an adequate level throughout the period of compulsory education, the percentage of interactional adjustments used would gradually decrease, pupils would become far more competent at listening, and thus have the opportunity of developing better listening skills, which would be of use not only in their foreign language learning but also in other walks of life. 
Marcos Peñate is Associate Professor at the Faculty of Teacher Training, University of Las Palmas de Gran Canaria. He is coauthor of several TEFL textbooks for primary education, published by Oxford University Press.

Geraldine Boylan is Associate Professor and Vice-Dean of International Relations at the Faculty of Translation and Interpreting, University of Las Palmas de Gran Canaria. Her main area of interest is the teaching of language and culture.

\section{Notes}

1. For the purposes of this experiment, paraphrasing has been taken to mean complete reformulation of a phrase without repeating any words used in the previous SU.

\section{References}

Call, M. (1985). Auditory short-term memory, listening comprehension, and the input hypothesis. TESOL Quarterly, 19, 765-781.

Cervantes, R., \& Gainer, G. (1992). The effects of syntactic simplification and repetition on listening comprehension. TESOL Quarterly, 26, 767-770.

Cook, V. (1993). Linguistics and second language acquisition. Basingstoke: Macmillan.

Dunkel, P. (1991). Listening in the native and second/foreign language: Toward an integration of research and practice. TESOL Quarterly, 25, 431-457.

Ellis, R. (1985). Teacher-pupil interaction in second language development. In S. M. Gass \& C. G. Madden (Eds.), Input in second language acquisition (pp. 69-85). Rowley, MA: Newbury House.

Ellis, R. (1994). The study of second language acquisition. Oxford: Oxford University Press.

Enright, D.S. (1986). Use everything you have to teach English: Providing useful input to young learners. In P. Rigg \& D. S. Enright (Eds.), Children and ESL: Integrating perspectives (pp. 115-162). Washington, DC: TESOL.

Hakansson, G. (1986). Quantitative studies of teacher talk. In G. Kasper (Ed.), Learning, teaching, and communication in the foreign language classroom (pp. 83-98). Aarhus, Denmark: Aarhus University Press.

Hamayan, E., \& Tucker, R. (1980). Language input in the bilingual classrooom and its relationship to second language achievement. TESOL Quarterly, 14, 453-468.

Henzl, V.M. (1973). Linguistic register of foreign language instruction. Language Learning, 23, 207-227. 
Henzl, V.M. (1979). Foreigner talk in the classroom. IRAL, 17, 159-167.

Kellerman, S. (1992). I see what you mean: The role of kinesic behaviour in listening and implications for foreign and second language learning. Applied Linguistics, 13, 239-258.

Kleifgen, J. A. (1985). Skilled variation in a kindergarten teacher's use of foreign talk. In S. M. Gass \& C. G. Madden (Eds.), Input in second language acquisition (pp. 59-68). Rowley, MA: Newbury House.

Krashen, S. (1998). Comprehensible output? System, 26, 175-182

Larsen-Freeman, D., \& Long, M. (1991). An introduction to second language acquisition research. London: Longman.

Morley, J. (1991). Listening comprehension in second/foreign language instruction. In M. Celce-Murcia (Ed.), Teaching English as a second or foreign language (pp. 81-106). New York: Newbury House.

Pica, T., \& Long, M. H. (1986). The linguistic and conversational performance of experienced and inexperienced teachers. In R. Day (Ed.), Talking to learn: Conversation in second language acquisition (pp. 85-97). Rowley, MA: Newbury House.

Rubin, J. (1994). A review of second language listening comprehension research. The Modern Language Journal, 78, 199-221.

Saville-Troike, M. (1985). Cultural input in second language learning. In S. M. Gass \& C. G. Madden (Eds.), Input in second language acquisition (pp. 51-58). Rowley, MA: Newbury House.

Scarcella, R.C., \& Higa, C. (1981). Input, negotiation, and age differences in second language acquisition. Language Learning, 31, 409-437.

Scarcella, R.C., \& Higa, C. (1982). Input and age differences in second language acquisition. In S. D. Krashen, R. C. Scarcella, \& M. H. Long (Eds.), Child-adult differences in second language acquisition (pp. 175-201). Rowley, MA: Newbury House.

Seright, L. (1985). Age and aural comprehension achievement in Francophone adults. TESOL Quarterly, 19, 455-473.

Spada, N. (1994). Classroom interaction analysis. TESOL Quarterly, 28, 685-688.

Swain, M. (1993). The output hypothesis: Just speaking and writing aren't enough. The Canadian Modern Language Review, 50, 158-163.

Taguchi, N. (2001). L2 learners' strategic mental processes during a listening test. JALT Journal, 23, 176-201.

Tardif, C. (1994). Classroom teacher talk in early immersion. The Canadian Modern Language Review, 50, 466-481.

Van Patten, B. (1990). Attending to form and content in the input. Studies in Second Language Acquisition, 12, 287-301.

Wagner-Gough, J., \& Hatch, E. (1975). The importance of input data in second language acquisition studies. Language Learning, 25, 297-308. 
Wong-Fillmore, L. (1982). Instructional language as linguistic input: Second language learning in classrooms. In L. C. Wilkinson (Ed.), Communicating in the classroom (pp. 283-296). New York: Academic Press.

\section{Appendix}

\section{A. Excerpt from The Long Nose}

Jack lives with his mother and his brother Tom in the country. Jack is only eight years old, but Tom is twenty-five years old. The mother is very old. They haven't got any money but they have some food. They have potatoes, oranges, apples, etc., at the farm. They have eggs because they have two hens and milk because they have a cow.

Jack and his mother are very happy because they like eating potatoes, oranges, apples, and eggs. They also like drinking milk. But Tom is not happy at all because he only likes eating biscuits and drinking Coke. One day, Tom says to his mother and to his little brother, "I want to sell the hens and the cow because I want to buy biscuits and Coke." "No," says Jack. "That's a very stupid idea. We like eating eggs and drinking milk!"

\section{B. Excerpt from When Friends Come to Visit Us}

When friends come to visit us in the evening, they spend their time telling us that they are in a hurry and looking at their watches. It isn't that our friends are all very busy; it is just that we haven't got a television. People think that we are very strange. "But what do you do in the evenings?" they are always asking. The answer is simple. Both my wife and I have hobbies. We certainly don't spend our evenings staring at the walls. My wife enjoys cooking and painting and often attends evening classes in foreign languages. This is particularly useful as we always go abroad for our holidays. I collect stamps and am always busy with my collection. 
